\title{
American Exceptionalism Revisited: Tax Relief, Poverty Reduction, and the Politics of Child Tax Credits
}

\author{
Joshua T. McCabe, ${ }^{a}$ Elizabeth Popp Berman ${ }^{\mathrm{b}}$
}

a) Wellesley College; b) University at Albany

Abstract: In the 1990s, several liberal welfare regimes (LWRs) introduced child tax credits (CTCs) aimed at reducing child poverty. While in other countries these tax credits were refundable, the United States alone introduced a nonrefundable CTC. As a result, the United States was the only country in which poor and working-class families were paradoxically excluded from these new benefits. A comparative analysis of Canada and the United States shows that American exceptionalism resulted from the cultural legacy of distinct public policies. We argue that policy changes in the 1940s institutionalized different "logics of appropriateness" that later constrained policymakers in the 1990s. Specifically, the introduction of family allowances in Canada and other LWR countries naturalized a logic of income supplementation in which families could legitimately receive cash benefits without the stigma of "welfare." Lacking this policy legacy, American attempts to introduce a refundable CTC were quickly derailed by policymakers who saw it as equivalent to welfare. Instead, they introduced a narrow, nonrefundable CTC under the alternative logic of "tax relief", even though this meant excluding the lowest-income families. The cultural legacy of past policies can explain American exceptionalism not only with regard to CTCs but to other social policies as well.

Keywords: child poverty; tax credits; welfare states; fiscal sociology; historical institutionalism

Citation: McCabe, Joshua T., and Elizabeth Popp Berman. 2016. "American Exceptionalism Revisited: Tax Relief, Poverty Reduction, and the Politics of Child Tax Credits." Sociological Science 3: 540-567.

Received: March 16, 2016

Accepted: March 27, 2016

Published: July 8, 2016

Editor(s): Jesper Sørensen, Sarah Soule

DOI: $10.15195 / \mathrm{v3} . \mathrm{a} 24$

Copyright: (C) 2016 The Author(s). This open-access article has been published under a Creative Commons Attribution License, which allows unrestricted use, distribution and reproduction, in any form, as long as the original author and source have been credited. (0)(1)
$T^{\mathrm{T}}$ has been almost two decades since the U.S. Congress passed the Taxpayer 1 Relief Act of 1997, which introduced the popular child tax credit (CTC). Since its introduction, the CTC has grown by leaps and bounds to become a central component of family policy in the United States. Both Democratic and Republican policymakers have expanded its scope, widening eligibility and doubling the value of the credit to $\$ 1,000$ per child. By 2012 , outlays for the credit amounted to $\$ 56.8$ billion-more than the United States spent on traditional income support programs such as Temporary Assistance for Needy Families (TANF) and Supplemental Security Income (SSI). The child tax credit is now the fourth largest individual tax expenditure behind the exclusion of employer health contributions ( $\$ 118$ billion), the home mortgage interest deduction ( $\$ 68$ billion), and the earned income tax credit ( $\$ 59$ billion). While these other tax expenditures have been discussed as part of the "hidden welfare state" (Hacker 2002; Howard 1997; Mettler 2011), the child tax credit, and the politics behind it, has received little attention from sociologists or political scientists.

The introduction of the child tax credit presents an intriguing case for those interested in welfare states and public finance. In the 1990s and early 2000s, policymakers in the liberal welfare regimes (LWRs) of Australia, Canada, New Zealand, United Kingdom, and the United States converged on the introduction of child 
tax credits in response to growing concerns about child poverty in their respective countries. This was part of a larger "fiscalization" of social policy, or the growing use of tax policy to assist families (Ferrarini, Nelson, and Höög 2012).

Within this broader convergence, however, the American child tax credit was exceptional. In other LWRs, these CTCs were refundable, meaning that families could claim the full value of the credit regardless of their tax liability. If a family's tax liability was less than the value of the credit, the government would send a check for the difference. The United States, on the other hand, introduced a nonrefundable child tax credit that limited the maximum value of the credit to the family's income tax liability (see Figure 1). In effect, this excluded most poor and many working class families from the benefits of the CTC, despite its initial rationale as an antipoverty policy. ${ }^{1}$ Why did the United States diverge from otherwise similar countries as the only one to introduce a child tax credit that did not reach the poorest families?

The most prominent explanations for why some groups receive social benefits while others do not focus on the perceived deservingness of target populations (Katz 1996; Schneider and Ingram 2005; Steensland 2008). In LWRs, the legacy of Poor Law distinctions between the undeserving "welfare poor" and the deserving working poor limit policymakers' ability to extend the same benefit to both groups. But CTC benefits were extended to the "welfare poor" in most LWR countries, largely without debate, at the same time that U.S. policymakers denied such a benefit to similar families. Because these countries all share the cultural distinction between the deserving and undeserving poor, it cannot explain the policy divergence.

Instead, we build on theories about the institutionalization of cultural categories by arguing that policies also institutionalize distinct "logics of appropriateness" (March and Olsen 2008) that can constrain policymakers trying to expand benefits, even to seemingly deserving target populations such as children. For a policy to be implemented, it is not enough that recipients are seen as deserving. There must also be an appropriate match between the type of benefit and the category of recipient.

Focusing on the "most similar" (George and Bennett 2005) cases of Canada and the United States, we demonstrate that the former's historical legacy of family allowances institutionalized a logic of "income supplementation for families" that enabled Canadian policymakers to extend the benefits of child tax credits to all children. Other LWR countries shared Canada's history of family allowances and had a similarly smooth transition to refundable CTCs.

Lacking a history of family allowances, U.S. policymakers instead relied on the legacy of tax exemptions, which institutionalized a logic of "tax relief for taxpayers" and constrained their ability to extend benefits to those perceived as nontaxpayers. While initial promoters of a refundable CTC intended it as a tool for reducing child poverty, proponents found it hard to keep "children"-a category with a universally positive valence-at the center of debate, even though the debate itself was over a child tax credit as a policy to tackle child poverty. Instead, refundable child tax credits were quickly stigmatized as "welfare" and the entire debate shifted to conflicts over who exactly counted as a taxpayer worthy of a nonrefundable CTC. This contrasts sharply with what happened in Canada (and other LWRs), where concerns about tax relief were completely absent from policy discussions and refundable CTCs were perceived as "taking children off welfare," not extending 


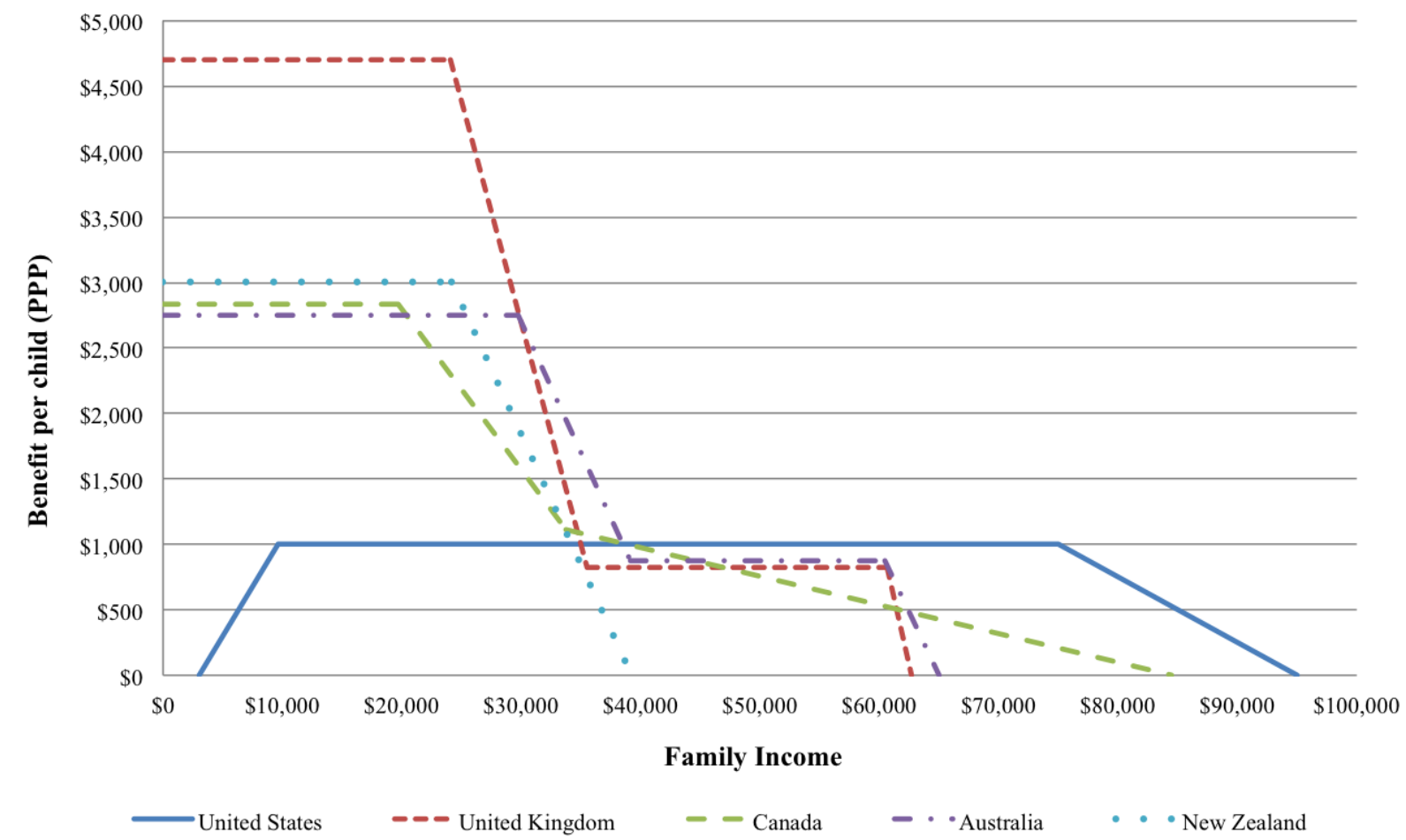

Source: Author's calculation, various national treasury/revenue department reports.

Figure 1: Child tax credit parameters in liberal welfare regimes (2011).

it to them. Despite the two countries' otherwise remarkable similarities, Canada introduced a refundable Child Tax Benefit, while the United States established a nonrefundable Child Tax Credit.

\section{The Cultural Legacies of Public Policies}

The last decade has seen the relationship between cultural sociology and historical institutionalism flourish. In particular, there has been a new appreciation for the process through which policy legacies exert a cultural influence that shapes and constrains later actors attempting to make significant policy changes (Best 2012; Brown 2013; Pedriana and Stryker 1997; Schneider and Ingram 2005; Skrentny 2006; Steensland 2008). The dominant approach focuses on how particular target populations or cultural categories become institutionalized through policy and shape who policymakers and the public see as worthy of benefits. Steensland (2008), for example, documents the inability of U.S. policymakers to introduce a guaranteed annual income program in a relatively favorable environment because of concerns over giving unrestricted cash benefits to the "undeserving poor." Similarly, Best (2012) notes that policy changes affecting how medical research was funded eventually led to less support for diseases perceived to be related to poor lifestyle 
choices (i.e., where the affected are "unworthy") relative to those unrelated to personal decisions.

While it is well established that moral distinctions between types of recipients affect policymakers' generosity, it is less clear why certain categorizations become salient at some moments but not others. In Canada, the CTC debate focused on children and their needs; the distinction between taxpayers and welfare recipients never had much traction in it, even though it was central to other political conflicts in Canada. In the United States, by contrast, the taxpayer versus welfare recipient distinction quickly came to dominate the conversation about CTCs, and the unifying category of "children" became less relevant.

To understand this divergence, we must look not only at which target populations are seen as deserving of benefits but also at what exactly it is they deserve. As Skrentny (2006:1803) notes in his study of how various groups were included or excluded in affirmative action policy, "Worthy/unworthy are indeed important basic categories in all social policy making, but by themselves they do not explain which policies go to which groups. Elites may perceive two groups as both worthy of policy but not... the same policy." In order to understand why sympathetic groups may be excluded from the benefits of a given policy, we must examine the particular "logic of appropriateness" behind the policy in question.

March and Olsen (2008) argue that these logics of appropriateness "define what are legitimate arguments and standards of justification and criticism in different situations." The legitimacy of a policy not only depends on who is receiving it and whether it is effective but also how they are receiving it. There must be a match, so to speak, between particular categories of beneficiaries and particular types of benefits. Skrentny (2006) shows how this worked in the case of affirmative action: because the policy was first developed with African-Americans in mind, groups perceived as definitionally similar to African-Americans (American Indians, Asian Americans, Latinos) had the easiest time being incorporated into affirmative action policy, while women had more difficulty and white ethnics had no success at all.

Others have shown that changing perceptions of target populations can lead to a shift in which logics are most prominent. When policymakers came to see disease victims, not doctors, as the primary beneficiary of medical research funding, they concomitantly shifted from a logic of science to a logic of mortality in deciding which diseases to fund (Best 2012). Furthermore, in the aftermath of U.S. welfare reform, Brown (2013) finds that states that perceived Hispanic immigrants as threatening followed a racial logic in determining the severity of punitive new rules, while if they thought illegal immigrants threatened them, policymakers used a legality logic instead.

The question then becomes why any particular logic dominates in a given situation. Building upon this work, we argue that in addition to institutionalizing cultural categories, policies also institutionalize distinct logics of appropriateness that are reinforced over time and constrain future policymakers. Families with children have been receiving direct cash benefits from LWR governments in one form or another for over a century. We identify three logics-and the policies in which they have become institutionalized - that have been crucial in governing whether children are seen as deserving of specific benefits. 
The first is the logic of income support for destitute families. According to this logic, families are deserving of relatively generous benefits to keep them out of deep poverty if they find themselves unable to earn income because of unemployment beyond their control. Most famously institutionalized in the English Poor Law of 1834 but also through the creation of "mothers' pensions" in the United States and Canada, this logic governs what would later be called social assistance or welfare (Little 1998; Skocpol 1992). The second is the logic of tax relief for taxpayers. According to this logic, families should be exempt from paying taxes until they have enough income to avoid poverty and support themselves. This logic was institutionalized in tax exemptions tied to number of dependents during the rise of mass income taxation around the turn of the twentieth century (Carluccio 1993; Seltzer 1968). By the 1920s, both of these logics were firmly institutionalized into public policies across the industrialized world. In the United States, they continue to be the dominant logics governing direct cash benefits to families with children.

In Canada and other LWR countries, but not in the United States, a third logic emerged in the 1940s: the logic of income supplementation for families with children. According to this logic, neither wages nor unemployment benefits take into consideration the fact that some people support dependent children while others do not. This necessitates small universal cash supplements to families with children, which prevents poverty among working families without removing work incentives for the unemployed (Blake 2009; Macnicol 1980). This logic was institutionalized in the family allowance or child benefit policies that were introduced in every LWR except the United States in the 1940s, as part of a larger process of postwar reconstruction.

The first two logics make categorical distinctions between families in different situations: the truly destitute versus income-earners of modest means. Providing tax relief to the welfare poor is seen as inappropriate because these families do not pay income taxes. Providing income support to working families is seen as inappropriate because they lack the need for it and likely wish to avoid the stigma attached to it. But the logic of supplementation transcends these boundaries. Policymakers may appropriately provide income supplements to all families, including both the welfare poor and taxpayers, because the logic is based on family size rather than ability to work or tax burden.

It is this third logic that served as the springboard for refundable tax credits in Canada and other countries but was absent in the United States. Beginning in the 1970s, LWRs (including the United States) increasingly channeled benefits through the tax system, where they would not be counted as spending, in order to obfuscate their costs in the face of mounting pressures for austerity. In this environment, child tax credits became a popular policy option for expanding family benefits. By the time child poverty became a major issue across the English-speaking world in the early 1990s, a consensus had formed that CTCs were the best policy option for tackling poverty within families.

Child tax credits could be justified using either of two logics: were they child benefits governed by the logic of income supplementation, in which case a refundable credit was most appropriate, or tax credits governed by the logic of tax relief, in which case a nonrefundable credit was most appropriate? The answer, rather than being contingent on the party in power or the country's general level of 
conservatism, hinged on whether the logic of income supplementation had been institutionalized through past policies.

In both Canada and the United States, policymakers saw the credits as a way to ease the economic pressures families were experiencing. But they drew on different policy legacies in thinking about who were appropriate recipients of CTCs. In both countries, welfare was increasingly seen as problematic. But in Canada, CTCs were seen as an off-budget way to restore the value of family allowances, which had been eroding because of inflation. Following the logic of income supplementation, it was only appropriate that such a benefit would go to all families, and thus that the tax credit would be refundable. Those families' status as workers or taxpayers was irrelevant. Indeed, Canadian policymakers explicitly argued that the refundable CTC would "take children off welfare."

In the United States, however, CTCs were quickly defined as a form of tax relief. Because only taxpayers were deserving of tax relief, making CTCs refundable was inappropriate and equivalent to welfare. Those proponents who tried to argue for the legitimacy of income supplementation across a wide range of families were quickly shut down, as the United States had no historical legacy of family allowances to institutionalize this logic. Instead, the United States created a nonrefundable CTC, which avoided the problem of expanding "welfare" but did nothing for the poorest children, whom CTCs were originally intended to help.

\section{Research Design and Methods}

The shift toward refundable CTCs looks similar across a range of liberal Englishspeaking welfare states, including Australia, Canada, New Zealand, and the United Kingdom (Blake 2009; Hodgson and Boden 2008; Nolan 2002; Waldfogel 2010). The fact that the United States has a deviant outcome-making the CTC nonrefundable and thus unavailable to children in the lowest-income families-that is not immediately explicable makes it a useful negative case (Emigh 1997). We begin with the logic of Mill's method of difference, which assumes that if a positive and negative case are similar on all relevant dimensions but one, the dimension on which they differ is the cause, effect, or necessary part of the cause of the difference in outcome (Mill 1843). Mill's method, however, is only of use as a starting point because in the social world, no cases are truly identical on all dimensions but one, and outcomes may have multiple causes or occur probabilistically rather than deterministically (Lieberson 1991).

We thus also draw on within-case methods (George and Bennett 2005) to test the argument that the absence of a legacy of family allowances was what made the United States different. The method of congruence, which assesses the ability of a theory to predict the outcome of a given case, allows us to rule out competing explanations, including those of partisan and interest group preferences, the advantage of cross-class support, national culture differences, and shifts toward workfare. Process-tracing, which attempts to follow the chain of events linking cause and effect, allows us to build support for our alternative explanation: that the availability of a "logic of income supplementation," which was a legacy of family allowance policies, led policymakers in most LWR countries to see refundable tax 
credits as an appropriate, nonstigmatized way to help families, while in the United States, tax credits were forced into a dichotomy in which they were seen either as a benefit for taxpayers (if nonrefundable) or, if refundable, as akin to welfare.

While the argument holds for Australia, New Zealand, and the United Kingdom, we focus on the United States-Canada comparison to make our case, following a long and fruitful tradition of United States-Canadian comparative studies (Eidlin 2015; Lipset 1990; Leman 1980; Maioni 1998; Myles and Pierson 1997). Of the LWRs, Canada is the most similar to the United States in ways relevant for our puzzle. Both countries had a newfound concern with child poverty in the early 1990s, both undertook major welfare reform during this period, and both countries saw the same confluence of political actors-specifically, an alliance of profamily conservatives and left-leaning think tanks-push for CTCs. The two countries' many similarities limit the factors that might potentially explain why they structured their CTCs so differently, thus providing the strongest test of our explanation.

We develop this argument by first briefly discussing the initial institutionalization of the three logics through income support programs, tax exemptions for dependents, and (in the case of Canada) family allowances in the first half of the twentieth century. We then demonstrate how in the 1970s, in the face of economic pressures on families and budget constraints for governments, Canada reinforced the logic of income supplementation, while the United States continued to focus on tax exemption. Finally, we closely examine the politics behind Canada's unproblematic introduction of the refundable Child Tax Benefit in 1992, contrasting it with the failure of U.S. proposals for a refundable CTC during this same period and the eventual triumph of a nonrefundable CTC in the Taxpayer Relief Act of 1997. After immersing the reader in the details of the two cases, we examine alternative explanations and describe their shortcomings relative to our own as well as briefly returning to the other LWR countries.

Our account is based on government reports, congressional and parliamentary debates and hearings, newspaper and magazine accounts, think tank and policy organization publications, and Congressional Quarterly reports, as well as the secondary literature on these policy debates. The wide range allows us to triangulate data to ensure that it is accurate and representative (Brown 2013).

In addition to traditional newspaper coverage in The New York Times, The Washington Post, and The Globe and Mail, we examined a number of sources of public discourse, including press releases, public speeches, and think tank documents from major players such as the Heritage Institution, Center for Budget and Policy Priorities, and Caledon Institute for Social Policy. Using ProQuest Congressional, we searched the Congressional Record for mentions of the child tax credit during the $101^{\text {st }}$ through $105^{\text {th }}$ sessions of Congress, revealing hundreds of reference points. ${ }^{2}$ We also examined the transcripts of all eight major congressional committee hearings on child tax credit proposals between 1991 and 1995. These hearings make up the heart of our evidence, as they are places where the logic behind policy proposals are made most explicit (Guetzkow 2010:179). We followed a similar process for the Canadian case, examining parliamentary records from Hansard and hearings in the House of Commons and Senate. 
This public discourse was triangulated with CQ Weekly reports on politics behind the scenes as well as private internal documents from various archives. These include hundreds of page of memos and correspondences from the Daniel P. Moynihan Papers at the Library of Congress, the Rod Gram Senatorial Files at the Minnesota Historical Society, and the Elana Kagan Collection, Domestic Policy Council Collection, Department of the Treasury Administrative History Collection at the William J. Clinton Presidential Archives, and various government reports as well as internal cabinet memos at the Library and Archives Canada.

\section{The Great Divergence of the 1940s}

Prior to the advent of World War II, public policies institutionalized two distinct logics justifying benefits for children in the United States and Canada as well as in other liberal welfare regimes. First, the Poor Law tradition led to laws institutionalizing the logic of income support for the destitute. By the 1930s, most states and provinces had passed "mothers' pension" laws providing income support for very needy families with children; eventually, these programs became federal (Little 1998; Skocpol 1992). Second, the creation of tax exemptions for children established another way government could legitimately assist families. As tax expenditures, child exemptions have received less attention from historians than other welfare state measures. Nevertheless, they were a major social policy innovation during this period. As policymakers shifted to mass taxation on incomes in order to fund wars and budding new welfare states, they awarded special recognition to taxpayers with children. Initially, neither the U.S. nor Canadian income tax systems included dependent exemptions, but they were quickly added as taxes rose to generate revenue for World War I (Carluccio 1993:82; Seltzer 1968:39-40).

Thus, heading into World War II, the United States and Canada had institutionalized two appropriate ways for government to assist families: through income support for the destitute and by reducing the tax burden for everyone else. Like their American counterparts, Canadian policymakers made a clear distinction between tax exemptions for children and direct cash benefits, noting in the 1940s that "great care had to be taken in any monies given out from the treasury as distinguished from exempting portions of income already earned" (quoted in Kitchen 1979:45). It was legitimate for families to be exempted from taxes; it was not legitimate for them to receive benefits beyond that, unless they were impoverished and could not work.

While there were major (if unsuccessful) movements for family allowances in other liberal countries prior to World War II, family allowances were not under consideration in North America in those years. Writing in 1926, the official publication of Canadian social workers saw family allowances as "entirely foreign to present Canadian and United States practice" (Guest 1999:80). Years later, one observer remarked that "virtually no study has been given to the subject on this continent and it is totally new to the general public" (Cassidy 1943).

The idea of universal family allowances did not gain political traction until the 1940s, when it was proposed in the famed U.K. "Beveridge Report" as part of a larger postwar project for welfare state reconstruction. Reformers in many countries 
argued that employers did not account for family needs in wage decisions, leaving workers with children at a disadvantage. Introducing universal family allowances was one way to recognize the increased costs associated with childrearing. Universality smoothed labor market transitions (children would receive a continuous allowance as their parents moved in and out of the labor market), prevented social stigma, and avoided the work disincentives that often came with social insurance and income support programs (Macnicol 1980).

Spurred by the popularity of the Beveridge report, North American governments soon released their own Beveridge-style reports. In the United States, the National Resource Planning Board's (NRPB's) Work, Security, and Relief Policies (1941) was known popularly as the "American Beveridge plan." Its Canadian counterpart was Leonard Marsh's Report on Social Security for Canada (1943). All three reports were discussed at length by contemporaries as analogous documents laying out national strategies for postwar reconstruction via Keynesian economic management and social security measures (Cassidy 1943; Beveridge 1943; Burns 1943; Witte 1945).

But the North American reports diverged in one significant regard. The Marsh report, written subsequent to Beveridge and modeled directly upon it, included a proposal for family allowances, thus placing them on the Canadian policy agenda for the first time. The NRPB report, which had been written before Beveridge but collected dust until the attention to Beveridge prompted President Roosevelt to release it, made no such proposal (Amenta 1998). The Canadian public was actually skeptical of the idea of family allowances-only $49 \%$ approved of the mostdiscussed proposal, and a mere 34\% saw it as a "necessary law" (Blake 2009:117). But despite this, the Beveridge momentum led the Canadian government to pass the Family Allowances Act in 1944. As Canadians became accustomed to receiving family allowances, the allowances quickly became a cherished part of social policy, with $90 \%$ of the population supporting them by 1955 (Blake 2009:156-159). This process institutionalized a third logic of appropriateness in Canada: the logic of income supplementation. Family allowances made it legitimate for government to provide cash supplements to families, without stigma, solely on the basis of their containing children.

This was the critical juncture at which the United States and Canada-previously on very similar welfare state paths-diverged. The United States, which pursued postwar reconstruction without seriously considering family allowances, never institutionalized a logic of income supplementation; Canada, along with other liberal welfare regimes, did. This divergence would have lasting ramifications, some of which would not become evident for decades.

\section{Reinforcing Logics in the 1970s}

The 1970s saw economic changes put new pressures on both Canadian and American families and governments. First, as the annual rate of inflation reached upwards of $10 \%$ in the 1970 s and 1980s, one of its many effects was to erode the value of childrelated benefits, whether that meant family allowances or tax exemptions. Second, chronic budget deficits ushered in what some have called an "era of permanent austerity" in which policymakers became increasingly concerned with constraining 
spending (Pierson 2001; Schäfer and Streek 2013). Austerity changed the costs and benefits of using the tax system for social policy purposes. Because tax credits showed up on the budget as revenues not collected rather than as outlays, they became more attractive to policymakers looking to provide benefits to families while avoiding new spending.

Policymakers in both countries responded to these pressures by diagnosing their source - the erosion of existing benefits-and proposing policy changes to fix it. In the process, the two countries reinforced different logics of appropriateness, even as both began to focus more on providing social benefits through the tax system.

In Canada, policymakers pointed to the erosion of family allowances, the real value of which had fallen from $4.7 \%$ of average family income in 1945 to $1.8 \%$ by 1971 (Battle 1988). In 1973, the Liberal government tripled their value in recognition that inflation affected all children by reducing their benefits. But further efforts to increase child benefits ran into budget constraints. After a 1978 economic summit at which world leaders decided that government spending was causing runaway inflation, Prime Minister Trudeau announced that the government needed to cut $\$ 2$ billion in spending from the federal budget (Haddow 1993:152). Some cabinet ministers feared that family allowances, one of the largest government programs, would be a prime target for spending cuts.

To avoid this, ministers Monique Bégin and Jean Chrétien crafted legislation to reduce family allowances while simultaneously introducing a new income-tested Refundable Child Tax Credit (RCTC). Because tax credits were counted as "revenues not collected" rather than expenditures, this deficit-neutral change appeared to be a spending reduction (Blake 2009:247-250). But despite being part of the tax system, the new RCTC was perceived as fitting squarely within the child benefit system. The Department of Finance, for example, explained that the RCTC was "quite independent of the tax system and like the current family allowance program would still involve monthly cheque delivery" (Department of Finance 1978). It was explicitly intended to recreate family allowances within the tax system, so the possibility that the credit might not be fully refundable was never even raised.

During the 1980s, the importance of the RCTC gradually grew as governments on the left and the right increased the RCTC while letting inflation erode family allowances (Department of Finance 1984). The full transition to a CTC would not take place until the 1990s. But in the meanwhile, the moves made to address economic pressures and budget constraints reinforced the logic of income supplementation, even as the policy instrument changed: it was legitimate to assist a wide range of families with cash simply because they contained children, and such assistance could be given without stigma or regard to work status. It was equally appropriate for that assistance to take the form of lower tax bills or a check sent by the government.

Unable to point to eroding family allowances, American policymakers instead looked to the erosion of the dependent exemption to the income tax as a source of pressures on families. While some Democrats would have preferred to expand direct spending on child poverty, as in Canada, the broader economic and political climate made this impossible. Instead, a crucial report on the taxation of families turned the attention of both left and right toward the eroding dependent exemption. Treasury 
economist Eugene Steuerle found that the value of the dependent exemption had plummeted by over $50 \%$ since 1948, hitting families with children hardest (Steuerle 1983). Steuerle himself was surprised by the size of the decline, and liberal child poverty advocates and conservative profamily groups converged around Steuerle's finding. Beginning in 1984, Congress held an unprecedented number of hearings highlighting the growing tax burden on families in or near poverty (Primus 1989). In each and every one of these, liberal advocates pointed to inflation-induced erosion of the dependent exemption as the sources of the problem. Similarly, the conservative Family Research Council (FRC) connected declining exemptions with family issues, telling Congress that "greater economic pressure caused by this increased tax burden may very well be the cause of many national problemsincluding divorce, crime, drug abuse, child abuse and runaway children" (U.S. House 1985a:106, U.S. House 1985b). This alliance between profamily conservatives and antipoverty liberals pushed Congress and the Reagan administration to include a doubling of the dependent exemption in the 1986 tax reform (Brownlee and Steuerle 2004:169-170). This decision to help families by increasing the income tax exemption reinforced the logic of tax relief as a legitimate way to assist (taxpaying) families.

Thus, while Canadian and American policymakers shared an interest in assisting families under economic pressure and a similar disinterest in turning to welfare as the solution, the cultural legacies of past policies shaped what the two countries saw as legitimate and appropriate ways to help: income supplementation or tax relief. As both countries turned their attention to child poverty in the 1990s, they would continue to build on these distinct logics.

\section{Canada: Taking Children off Welfare}

The issue of child poverty began to gain global attention at the end of the 1980s. In Australia, child poverty became a major issue during the 1987 federal election, with Prime Minister Bob Hawke promising, "no Australian child will be living in poverty" within three years (Stanton and Fuery 1995:125). By 1999, U.K. Prime Minister Tony Blair was making a pledge to "end child poverty within twenty years" (Blair 1999).

In Canada, a 1989 House of Commons resolution to "eliminat[e] poverty among Canadian children by the year 2000" passed unanimously and took on a life of its own as both left-leaning antipoverty groups and conservative profamily groups used it to draw more attention to the issue (House of Commons 1991; Senate 1991; Wiegers 2002). Canada was also embarrassed on the world stage in 1990 when the World Summit for Children, co-chaired by Progressive Conservative Prime Minister Brian Mulroney, repeatedly highlighted the fact that Canada had one of the highest child poverty rates in the industrialized world (Guest 1999:239-242).

While both left and right were newly focused on lifting children out of poverty in Canada, neither side was enamored of expanding the welfare system in order to do so. Canadian conservatives, like those in the United States, saw welfare as morally problematic and encouraging dependency among recipients. But concern with welfare dependency and employment disincentives in Canada actually originated 
on the left. In 1987, the National Council of Welfare, an independent advisory body within the government, issued a scathing report of Canada's provincial welfare systems. The report, Welfare in Canada: The Tangled Safety Net (1987), brought attention to the concept of poverty traps-high implicit marginal tax rates and asset tests that created perverse incentives to stay on welfare. The council put the blame squarely on the shoulders of the system rather than the individuals acting within it (National Council of Welfare 1987:32). But even if the mood was not particularly punitive, there was no real constituency for solving child poverty through the expansion of income support.

Instead, policymakers across the political spectrum drew on the logic of income supplementation for families as a way to address it. The so-called "Family Caucus," a profamily group within the Progressive Conservative Party, pushed the idea of expanding the refundable child tax credit (RCTC) as a means to help poor children. Much like American profamily groups, the Family Caucus was made up of evangelical Christians opposed to "welfare," feminism, and homosexuality and in favor of what they saw as traditional family values, worrying about marriage penalties in the tax code and policies biased against stay-at-home mothers (York 1992). But unlike their American counterparts, Family Caucus members, drawing on the legacy of family allowances, saw it as completely appropriate for the government to send money to families with children. They used the new interest in child poverty to push reforms to the child benefit system, particularly ones that would help low-income families. MP Al Johnson, the Caucus's informal leader, told reporters, "We've got to get it visible and focused on the child. It's an issue that has very broad support in our caucus" (York 1991).

Family Caucus members made a clear distinction between "welfare" benefits and child benefits, whether administered through family allowances or a refundable tax credit. Caucus member MP Barbara Greene told reporters, "We'd like to see a guaranteed annual income for children [via refundable tax credits] to take them out of poverty....We want them off welfare" (York 1991). This striking, frequently repeated slogan-that government would be "taking children off welfare" by providing them a child benefit-is difficult to comprehend from the American perspective, in which there is no obvious moral distinction between sending families money because they have children and sending them money because they are in need. However, given the cultural legacy of family allowances in Canada, sending money for children completely lacked the stigma associated with welfare benefits.

The Canadian left also saw the RCTC as an effective way to address child poverty. Concerned with the "poverty wall" or "welfare wall" that prevented families on income support from transitioning into work without making themselves worse off (Battle and Torjman 1993; Social Assistance Review Committee 1988), they saw that a more generous RCTC would decrease such barriers by lowering the implicit marginal tax rate on work, thus decreasing welfare dependency even as it reduced child poverty. This was an explicit part of the rationale behind the Senate child poverty report (1991:29), and the left-leaning Caledon Institute played a key role in pushing the Finance Department to consolidate child benefits into a CTC for this very reason (Hale 2002:122). 
With support from right-leaning, profamily advocates and left-leaning, antipoverty advocates, the Progressive Conservative government expanded refundable tax credits in 1992, combining what was left of family allowances with the nonrefundable CTC and the RCTC into a new, income-tested refundable tax credit called the Child Tax Benefit (CTB). Again, refundability was never compared to welfare, as was happening in the United States; instead, a refundable tax credit was seen entirely different from welfare. The change was not portrayed as "tax relief" nor was it aimed explicitly at taxpayers, and it actually increased the total cost of child benefits from $\$ 4.5$ billion under the old system to $\$ 4.9$ billion under the new one (Department of National Health and Welfare 1992). Like the RCTC, it concentrated benefits on the poorest families with no income.

Shortly afterwards, the Progressive Conservative government was thrown out of office in response to an unpopular new federal value-added tax (McCabe and Major 2014). At the provincial level, antitax and antiwelfare backlashes also swept Alberta and Ontario in 1995 (Klassen and Buchanan 2009). Yet despite the new political environment, the now-ruling Liberal government was able to continue to expand the CTB using the same justification as its predecessors: tackling child poverty, taking children off welfare, and encouraging work (Battle 1999). The logic of income supplementation-distinct from income support and tax reliefthat had been institutionalized by family allowance policies in Canada provided policymakers with a springboard for refundable child tax credits. The absence of this logic in the United States, by contrast, would lead an initially similar debate to take a very different turn.

\section{United States: The Triumph of Tax Relief}

As was the case in the other liberal welfare regimes, the United States began talking seriously about child poverty in the late 1980s. A blue-ribbon National Commission on Children was created in 1987 to consider the status of children and their families (Public Law 100-203 §9136), and its interim report, published in 1990, emphasized the problem of child poverty (National Commission on Children 1990). Building off this momentum, Eugene Steuerle (whose earlier work had brought attention to the declining value of the dependent exemption) and Jason Juffras of the Urban Institute released a report recommending a fully refundable $\$ 1,000$ child tax credit in early 1991 as a means to help struggling families (Steuerle and Juffras 1991).

The proposal first gained attention at a 1991 congressional hearing on "reclaiming the tax code for American families." The hearing, convened by chairwoman Patricia Schroeder (D-CO), drew heavily on the logic of tax relief for taxpayers (e.g., U.S. House 1991a:3-4). In fact, there was a broad bipartisan consensus among participants, based explicitly on Steuerle's earlier research, that families were still facing significant economic pressures as a result of the erosion of the dependent exemption. The obvious response, which several participants proposed, was to increase the exemption.

Steuerle himself, however, introduced his child tax credit proposal as an alternative. He acknowledged that his earlier work had promoted a larger dependent exemption. But, he noted, "trying to make benefits more even and incentives for 
work and marriage better leads me more towards a credit these days" (U.S. House 1991a:100). Drawing on the logic of income supplementation that had worked in Canada, he and noted child poverty expert Timothy Smeeding emphasized the benefits of a refundable CTC in making the current system more pro-work and pro-marriage, and argued that it would "remove children from poverty... on an equitable basis, across all children and across all mothers" (U.S. House 1991a:24, $62)$.

Steuerle and Smeeding made the connection with family allowances clear. Smeeding emphasized that "we have about 19 to 20 percent of our children who are poor. The next nearest country is Britain with 12 percent. The Canadians only have 9 percent of their kids poor. Why? Because they have this refundable child allowance, this child grant, that is relatively modest, but it underlies the rest of the system" (U.S. House 1991a:62). Steuerle said a refundable CTC would do the same thing: "There's a game that's played, in calling a 'tax credit' what is little different than a 'family allowance."' But, he argued, "the difference is just a question of who administers the system" (U.S. House 1991:105).

One might expect pro-work, pro-marriage arguments to resonate with conservative profamily groups, as they had in Canada. But very quickly there was pushback from those groups against Steuerle and Smeeding's refundable CTC proposal. Even Steuerle and Smeeding's own arguments did not solely focus on the benefits of income supplementation as Canadian debates had, and they frequently referenced rising tax burdens on families as an additional justification for a CTC. But profamily groups used the logic of tax relief, much better institutionalized in the United States, to respond aggressively to the idea of a refundable CTC.

Notably, Gary Bauer, president of the conservative Family Research Council, took issue with the experts' indifference toward whether families receiving the proposed CTC were actually paying any taxes in the first place. Bauer unveiled his own proposal, in coordination with the Heritage Foundation, to offer a child tax credit "refundable up to the combined employer-employee level of the payroll tax" (U.S. House 1991a:59). He quickly tagged fully refundable tax credits as inappropriate, emphasizing the need to separate "tax relief mechanisms" from "wage supplement mechanisms." Even among working families, there was a "critical distinction" between "taxpaying families" and "non-taxpaying income-earners" that refundable CTC proposals ignored (ibid:60). Similarly, Congressman Dennis Hastert (R-IL) emphasized the "fine line between family tax policy and welfare reform," and warned that they "need[ed] to be careful not to get the two mixed up" (ibid:112). The competing logic of tax relief drew a sharp line between taxpayers under economic pressure who deserved a CTC because of an unfair tax burden and other families who had no inherent claim to government benefits. The hearing marked the first skirmish in a larger conflict between competing logics of appropriateness.

The case for a refundable CTC got its biggest boost two months later with the release of the National Commission on Children's report, Beyond Rhetoric: A New American Agenda for Children and Families (1991). The report saw a positive reception because of its bipartisan and unanimous endorsement of several policy recommendations, including a fully refundable $\$ 1,000$ child tax credit. The commission noted 
that "[ $\mathrm{t}]$ he United States is the only Western industrialized nation that does not have a child allowance policy or some other universal, public benefit for families raising children" (National Commission on Children 1991:94) and, like Steuerle and Smeeding, framed its proposed CTC as a pro-work alternative to income support programs:

Because it would assist all families with children, the refundable child tax credit would not be a relief payment, nor would it categorize children according to their "welfare" or "nonwelfare" status. In addition, because it would not be lost when parents enter the work force, as welfare benefits are, the refundable child tax credit could provide a bridge for families striving to enter the economic mainstream. It would substantially benefit hard-pressed single and married parents raising children. (National Commission on Children 1991:95.)

Several weeks later, the Senate Committee on Labor and Human Resources held a hearing on "economic pressures on working families" that returned to the question of a CTC. While the initial topic of the hearing was the eroding dependent exemption, Jason Juffras's testimony returned the emphasis to a CTC. Juffras, like Steuerle and Smeeding, alluded to tax relief in his statements about the increasing tax burden on families. But he also emphasized income supplementation as an appropriate type of benefit for families with children: "a child credit, something like that of $\$ 1,000$, would provide a floor of income for all families. It would be something that would be available whether you were on welfare or not on welfare, if you are in a single-parent family or not in a single-parent family" (U.S. Senate 1991a:56).

Yet once again, the pushback from critics using the logic of tax relief was almost immediate. The FRC's William Mattox drew a line around "taxpayers" as the appropriate target population and disparaged the National Commission on Children's proposed refundable CTC as "welfare-style cash transfers" (U.S. Senate 1991a:71). While the poorest children might at times need income support, what was called for in this case was "a pure tax relief mechanism" (U.S. Senate 1991a:70). House Budget Committee hearings saw similar responses, with Martin Kosters of the American Enterprise Institute arguing that refundable CTC proposals were "much more akin to increasing means-tested transfer payments than they are to giving tax relief" (U.S. House 1991b:12). Over the summer, support for a CTC grew among Congressional Republicans (Wednesday Group 1991). But in contrast to refundable proposals, these proposals sought to limit the total value of the credit to the family's combined payroll and income tax burden. Their proponents emphasized the distinction between refunding payroll taxes and a fully refundable credit, which would provide "cash welfare benefits to non-working families" (Rector and Butler 1991:12).

During the $102^{\text {nd }}$ congressional session, 14 different CTC proposals floated around Congress. Of the 10 sponsored by Democrats, seven were fully refundable. None of the four Republican-sponsored bills included fully refundable credits. Senator Jay Rockefeller's (D-WV) proposal for a fully refundable $\$ 1,000$ CTC was the first to be introduced in Congress, but both the Democrat-controlled Congress and the Republican Bush administration deemed it too expensive. As the CTC idea gained steam, more hearings on it were held in late 1991. In Canada and elsewhere, 
such conversations had been opportunities for conservatives to demonstrate their profamily, antiwelfare positions by positioning refundable CTCs as a means of "taking children off welfare." But in the United States, the logic of tax relief, with its concomitant view of refundability as equivalent to, rather than an alternative to, welfare, remained dominant among moderates and conservatives. This shaped which bill Democrats favored.

Among liberal Democrats, a proposal by Representative Thomas Downey (DNY) and Senator Al Gore (D-NY) was the favorite. The Gore-Downey proposal would provide a minimum $\$ 400$ refundable CTC available to families with no income and would increase to $\$ 800$ for working-class families. Increasingly, however, a proposal by Senators Lloyd Bentsen (D-TX), William Roth (R-DE), and Barbara Mikulski (D-MD) gained ground. This much smaller $\$ 300$ nonrefundable CTC was governed, like conservatives' proposals, by the logic of tax relief. The problem, as they explained it, was that "[f]amilies with children saw their taxes increase while their income dropped" during the 1980s (U.S. Senate 1991b:2). These legislators defined the problem in the terms determined by the dominant policy legacy of dependent exemptions - as families struggling with the burden of taxes, a logic entirely different from that used by profamily conservatives in Canada and elsewhere. It was because of this congruity with the logic of tax relief that the centrist Bentsen proposal was able to gain the favor of groups like the conservative Family Research Council. In their statement supporting Bentsen-Roth-Mikulski, the FRC noted,

Curiously, several prominent proposals promising "middle-income tax relief" (including the Rockefeller and Gore-Downey plans) make little or no distinction between welfare recipients and taxpayers with children. They offer refundable tax credits to all families, including low-income, child-present households where the household head is not married, gainfully employed, or receiving child support....Even if one believes greater cash assistance to welfare recipients is warranted, it is disingenuous to use the banner of "middle-income tax relief" to secure this result. (U.S. Senate 1991b:326.) ${ }^{3}$

Liberal Democrats argued that making the credit nonrefundable would mean onequarter of American children would receive no benefit whatsoever while another third from working families would receive less than the full amount (U.S. Senate 1991b:44). But it was the Bentsen nonrefundable tax credit that found its way into the doomed tax bill, which was passed by Congress and vetoed by President Bush in March 1992 (Clymer 1992). The election of President Clinton that year, a member of the National Commission on Children and initially a supporter of a refundable CTC, was not enough to keep it on the agenda. Realizing that refundable CTC proposals had been effectively stigmatized as "welfare," the Clinton administration and Congressional Democrats quietly dropped them from consideration (Evans and Novak 1993). No bills proposing refundable CTCs appeared after 1993-well before the Republican takeover in the following year's midterm elections.

After the Republicans took both houses of Congress in 1994, they quickly put the introduction of a nonrefundable CTC at the center of their agenda, calling it the "crown jewel" of their program. While a nonrefundable CTC passed Congress again in December 1995, this time it was President Clinton who vetoed the bill 
because of its simultaneous cuts to the Earned Income Tax Credit (EITC) (CQ Weekly 1995). Most notably, arguments based on the logic of income supplementation were completely absent by this point. The logic of tax relief prevailed. After the 1996 election, which left Clinton in the White House and Republican majorities in both chambers of Congress, there was a sense that some form of CTC would now be hammered out (Rubin 1996). The approach taken by liberal Democrats, who wanted a CTC that reached more low-income families, was particularly noteworthy. Any attempts to make the CTC refundable would be tainted with the stigma of welfare. Democrats' only chance was to strategically work within constraints set by the logic of tax relief.

Their opportunity arose in the summer of 1997 when three distinct nonrefundable proposals emerged from the House, Senate, and Clinton Administration (Clinton Digital Library, Box 2, Folder 18, June 1997). The difference between each involved the procedure for claiming tax credits referred to as "stacking." In this case, the question was whether low-income families should be able to claim the proposed nonrefundable CTC before the refundable EITC. The order would determine whether working families making less than $\$ 30,000$ annually would receive any benefits from the CTC (see Figure 2).

The Clinton administration wanted to stack the CTC before the Earned Income Tax Credit, but the proposal approved by the House Ways and Means Committee would make families apply their EITC before claiming the CTC. The proposal approved by the Senate Finance Committee split the difference, requiring families to apply half of their EITC before they could claim the CTC. Because the EITC wiped out some or all income tax liability for most families making less than $\$ 30,000$ a year, they would receive little or nothing from the House CTC proposal, which could only be claimed against income taxes. The Clinton proposal, on the other hand, would allow families to apply the nonrefundable CTC to their income tax liability before claiming the refundable EITC. The decision to focus on stacking, rather than refundability, was a conscious one employed by administration officials in order to co-opt the logic of tax relief:

All of us agreed that we did not want to allow the Republicans to be able to frame the message as Democrats for welfare payments at the expense of Republicans for tax credits for teens in middle class families. We reached consensus around a proposal that would give the tax credit to teenagers, and have partial refundability—but only to the degree that people paid payroll and income taxes beyond what they get in their EITC. In this way, we take away the Republican message on teenagers, keep some element of refundability, but keep our message that this is a tax cut only for people who owe federal payroll and income taxes. (Clinton Digital Library, Box 2, Folder 18, June 1997.)

Republicans pushed back, though, arguing that stacking a partially refundable CTC before the refundable EITC would allow some families to receive more in combined CTC and EITC benefits than they paid in federal income and payroll taxes. House Ways and Means Committee chair Bill Archer (R-TX) set off a firestorm when he declared that allowing families to claim the CTC before the EITC was tantamount to "welfare." He wrote to The New York Times, "Giving taxpayer money to people who 


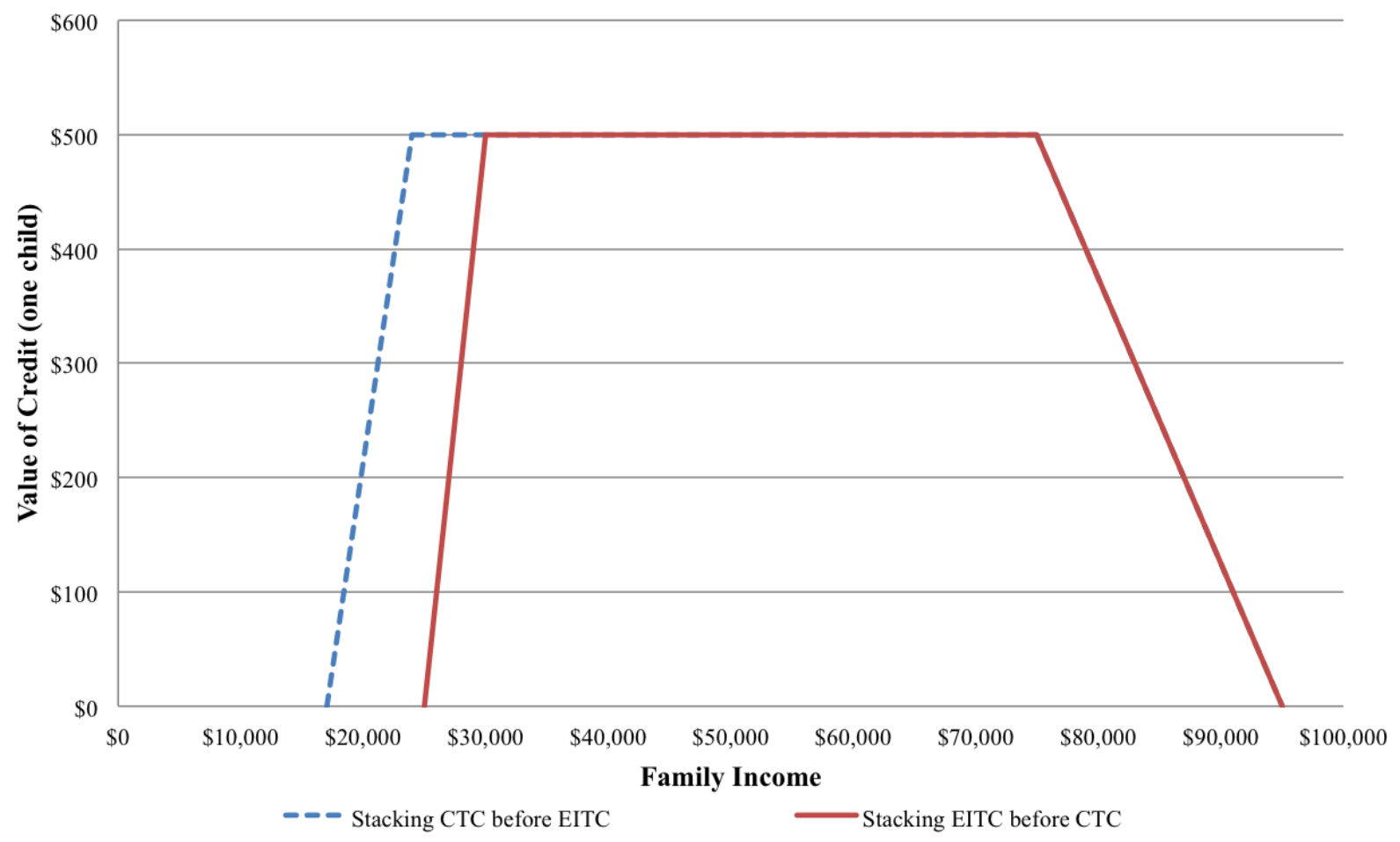

Source: Author's calculations based on Joint Tax Committee reports

Figure 2: Tax credit eligibility under each stacking proposal.

pay no taxes allows for a backdoor increase in welfare spending. My plan protects taxpayers by reserving relief only for those who pay taxes. It is not fair if lowerand middle-income workers get less tax relief so that Americans who pay no taxes at all can receive a larger check" (Archer 1997; see also Rubin and Hosansky 1997). Other Republicans, including House Speaker Newt Gingrich (R-GA), followed suit, calling the proposal a "welfare bill" (Bennett 1997).

Democrats responded aggressively, wielding the same logic of tax relief that had been used to defeat refundable CTC proposals. Now, they exclusively emphasized that Republicans were trying to deny the credit to worthy taxpaying families. The left-leaning Center for Budget and Policy Priorities, for example, released reports showing that " $[\mathrm{m}]$ ost of the children who would be denied the credit or have their credit reduced live in families that owe federal taxes. Their tax burdens often amount to several thousand dollars even after the effects of the Earned Income Tax Credit are accounted for. Claims these families owe no federal tax are not correct" (Shapiro and Greenstein 1997).

Major newspapers took Republicans to task for characterizing low-income working families as welfare recipients, telling stories of hypothetical or real-life families who would be denied the CTC under GOP proposals. Significantly, writers framed this as a denial of tax relief. For example, The Wall Street Journal told the story of a hypothetical family from Georgia: 
A starting police officer in Gwinnett County, GA-coincidentally part of Speaker Gingrich's district-is paid $\$ 23,078$ a year. If his family has two kids, it gets a $\$ 1,668$ earned income tax credit, which offsets its $\$ 675$ in federal taxes and yields a check for $\$ 993$. But that family pays $\$ 1,760$ in payroll taxes (most economists would also add the employer's share of payroll taxes too) and another $\$ 354$ in federal excise taxes. Thus, even after the EITC, this police officer's family's out-of-pocket federal taxes would be at least $\$ 1,121$ and in reality more like $\$ 2,881$. (Hunt 1997.)

The Washington Post and The New York Times also reacted with outrage (e.g., Herbert 1997; Washington Post 1997). The Congressional Record was filled with the stories of similar families. Crucially, these counterframes used the logic of tax relief to argue that these families were worthy. By mid-July, as talks began to reconcile the House and Senate bills, it was clear that Democrats were winning the public relations battle. Polls showed the public supported Clinton's position. Republican rhetoric describing the stacking proposal preferred by Democrats as "welfare" ceased. In the final compromise, which became part of the aptly named Taxpayer Relief Act of 1997, the CTC was stacked before the EITC as Democrats had preferred, with only minor concessions to Republicans. The Democrats scored a win-but only by arguing that the credit should be extended to more taxpayers and defining "taxpayers" more broadly than Republicans.

In Canada, by contrast, neither liberals nor conservatives had seen tax relief as a goal of CTCs, despite the fact that antitax politics were as prominent in Canada in this era as they were in the United States (McCabe and Major 2014). Moreover, the legacy of family allowances meant that a wide range of Canadians believed that it was legitimate for government to supplement the incomes of families with children, despite their skeptical assessments of welfare. But the absence of such a cultural legacy in the United States made tax relief seem much more legitimate than income supplementation, which prevented a refundable CTC from being considered seriously.

\section{Discussion and Conclusion}

Since the 1970s, policymakers in liberal welfare regimes having increasingly shifted toward the use of tax credits for social policy purposes. Child tax credits, in particular, were introduced as part of larger movements to tackle child poverty. The United States, however, was alone among these countries in introducing a nonrefundable CTC that did not reach the lowest-income families and since has only made limited moves to expand its reach. We argue that the United States diverged because of the cultural legacy of past policies, which institutionalized different "logics of appropriateness" regarding what sorts of benefits could legitimately be given to particular groups.

All LWRs, including the United States, shared a policy tradition that portrayed income support as appropriate for the destitute and tax exemptions as appropriate for taxpaying families with children. But the adoption of family allowances by Canada, Australia, New Zealand, and the United Kingdom in the 1940s institutionalized a third logic in those countries: the logic of income supplementation, which 
made it appropriate for government to provide cash benefits to all families, without stigma, to defray the cost of having children.

As the LWRs fiscalized their social policies after the 1970s, they began to convert family allowances into refundable child tax credits. We have shown how this looked in Canada: it was uncontroversial, was supported by left and right, and was perceived as "taking children off welfare," not putting them on it. The politics of this process were similar in the United Kingdom, Australia, and New Zealand (Blair 1999; Cullen 2004; HM Treasury 1999; Hodgson 2005; Nolan 2004; Stanton and Fuery 1995). In each country, refundable CTCs were seen an extension of family allowances, there was no focus on CTCs as a way to provide tax relief, and the question of refundability was not a political flashpoint.

In the United States, however, the lack of a family allowance legacy meant that there was no tradition of near-universal cash benefits for families. While the original, fully refundable CTC proposals in the United States were also a response to child poverty, the legitimacy of refundability was quickly challenged. Without a strong logic of income supplementation, CTCs were seen as either tax relief for taxpayers or welfare for nontaxpayers. In an antiwelfare environment, there was no support for the latter, and the possibility of full refundability quickly disappeared. Liberals were able to expand the reach of the credit somewhat beyond conservatives' proposals but only by defining "taxpayer" more broadly than conservatives did, not by arguing for the legitimacy of income supplementation. Without the institutionalized legacy of family allowances, the poorest families remained locked out of the CTC's benefits in the United States.

Several other theories might potentially explain the structure of CTCs in the United States and other liberal welfare regimes, but none fits as well as the policy legacy explanation. State-centered approaches to social policy emphasize that successful programs require cross-class support (Korpe and Palme 1998; Prasad 2006). But these theories do not explain variance in cross-class coalitions. If anything, they would lead us to expect refundability in the United States as elsewhere because refundability would bring low-income families into the supporting coalition (Pierson 1994). Thus, while the outcome in other LWRs is compatible with a state-centered approach, such an approach has no obvious explanation for U.S. exceptionalism.

Some political culture explanations focus on the legacy of the English Poor Laws in institutionalizing distinctions between the "deserving" working poor and "undeserving" welfare poor in social policy (Bertram 2007; Steensland 2008). This legacy has resulted in a trend toward "workfare" in liberal welfare regimes in recent decades. Such explanations would suggest that CTCs would be favored if they were seen as encouraging work and disfavored if they were seen as expanding welfare. But American and Canadian actors both saw their preferred version of the CTC as promoting work over welfare. The key difference is that Americans saw refundability as equivalent to welfare, while Canadians saw it as a distinct alternative. The Poor Law legacy, which the two countries shared, cannot explain their divergent perception of the same policy.

Power resource approaches focus on the support or opposition of influential actors, such as business and labor groups, political parties, and advocacy groups, in explaining the structure of tax and social policies (Block 2009; Gitterman 2010). 
These interest-based explanations might predict that left-leaning parties, labor groups, and antipoverty advocates would favor refundability while right-leaning parties, business groups, and conservative movements would support nonrefundability.

In the case of child tax credits, business groups in the United States and Canada were unconcerned with their distributive structure; consistent with Howard's (1997) observation regarding other tax credits, business groups' only concern was the overall cost (U.S. House 1991c). And labor groups, which represented workers less likely to be affected by whether the credit was refundable, took no strong position.

Political parties, profamily conservatives, and antipoverty advocates all did take positions on the structure of CTCs. In both Canada and the United States, right-leaning parties introduced the credits with the support of both conservative profamily groups and liberal antipoverty advocates. On other social policy issues, Canadian and American groups took similar positions to one another. For example, in both countries, conservative groups supported welfare reform and antipoverty groups opposed it. But United States and Canadian interest groups diverged on the issue of CTC refundability. In Canada, the Progressive Conservative Party, with the support of the Family Caucus and the Caledon Institute, introduced a refundable CTC. In the United States, Congressional Republicans, with the support of the Family Research Council and the Center for Budget and Policy Priorities, introduced a nonrefundable CTC. The different outcomes were not due to the relative strength of left and right interest groups in the two countries but resulted from those groups' perceptions of whether income supplementation was a legitimate type of benefit for families.

National culture explanations might account for American exceptionalism by arguing that the United States is simply more antitax, antispending, and antiredistribution than Canada and other liberal welfare regimes (Lipset 1990; Lockhart 2012). Even if CTCs were introduced by conservatives in both the United States and Canada, perhaps American conservatives were just more conservative than Canadian conservatives and this accounts for the policy divergence. But there are two problems with this argument. First, it is not clear that Canadians were more conservative by these measures outside of the CTC. Canada, like the United States, was strongly antitax in this period, and the United States was willing to expand other types of spending on child poverty (McCabe and Major 2014; Weaver 2000:173). Both countries were undertaking workfare reforms, and Ontario, the largest Canadian province, even had its own version of Newt Gingrich's "Contract with America" (Bashevkin 2002).

Second, the relevant question is not so much whether conservatives were more "conservative" in one country or the other but rather what is defined as "conservative" in different times and places. After all, American conservatives consistently vote for increases in policies like Social Security and Medicare because these are, for historical and cultural reasons, not seen as opposed to conservatism in the United States. U.S. and Canadian conservatives both saw themselves as being opposed to welfare in the 1990s and demonstrated that opposition in other ways. The key difference, which national levels of "conservatism" cannot explain, is why refundable 
tax credits were defined as similar to welfare in one country and an alternative to it in the other.

Finally, we might look to America's unique racial history and to the racialized nature of welfare policy in the United States to explain its divergent outcome. Historically, though, American racism did not prevent the creation of new social programs; instead, blacks were excluded either implicitly or informally (e.g., through "suitable home" provisions in Aid to Dependent Children; Patterson 1994). But nonrefundability excluded more whites than blacks from the CTC. And while racialized welfare politics might explain why "welfare recipients" lost out to "taxpayers" in the CTC debate, "welfare recipients" were losing ground in other LWR countries in the 1990s as well (Bashevkin 2002). The key difference is that outside the United States a refundable CTC never came to be seen as welfare in the first place.

Alternative theories can explain other aspects of U.S. and Canadian welfare policy in this period, but none of them provide a better explanation for American exceptionalism on child tax credits than the cultural legacies of past policies. This article thus makes three contributions to the literature on welfare states. First, it helps to explain an important anomaly in a very large ( $\$ 57$ billion) and understudied American social program.

Second, it identifies a specific mechanism through which historical policy decisions can have ongoing political effects. Other scholars have shown how policies institutionalize target populations or cultural categories (Katz 1996; Schneider and Ingram 2005; Steensland 2008). But building on March and Olsen's (2008) concept of "logics of appropriateness," we show how past policies can institutionalize matches between particular categories of beneficiaries and types of benefits. The presence or absence of such legacies constrains policymakers seeking to provide new kinds of benefits, even to populations (like children) otherwise seen as deserving. Though the subsequent history of the U.S. CTC suggests that ongoing efforts can partially counter such legacies, it is clearly a long, upward struggle. In other countries, by comparison, the bright line between refundability and nonrefundability, which was so meaningful in the United States, was simply irrelevant.

Finally, our analysis suggests that the ability of the United States to use tax credits to help the poorest families is likely to remain severely limited by its lack of a family allowance legacy. Recent recommendations to expand the child tax credit and make it fully refundable (Garfinkel, Rainwater, and Smeeding 2010; Waldfogel 2010) are technically efficient for fighting child poverty but may be politically untenable given existing policy legacies. The stigma of welfare, often thought to be the main obstacle to refundability, is not the most important part of the story. The real problem is that such a policy became defined as welfare in the first place, which it never was in the LWR countries with a history of family allowances. Overcoming this will either require institutional change - which is not impossible, but very hard (Streek and Thelen 2005) — or choosing a strategy better suited to success given the unique policy legacies of the United States. Without taking these into account, efforts to change social policy-whether through the tax system or elsewhere-are unlikely to be successful. 


\section{Notes}

1 The CTC was not refundable at all when first introduced. It has since been made partially refundable but still excludes the poorest families; see Figure 1.

2 We used multiple variations on the same concept, including child tax credit, family tax credit, tax credit for children, and tax credit for families.

3 See also U.S. House (1991c) for similar examples of this logic at work.

\section{References}

Amenta, Edwin. 1998. Bold Relief: Institutional Politics and the Origins of Modern American Social Policy. Princeton: Princeton University Press.

Archer, Bill. 1997. "Tax Plan Gives Most Relief to the Middle Class." New York Times. 16 June: A14.

Bashevkin, Sylvia. 2002. Welfare Hot Buttons: Women, Work, and Social Policy Reform. Toronto: University of Toronto Press.

Battle, Ken. 1988. "Child Benefits in Decline." Policy Options: 3-7.

Battle, Ken. 1999. "Child Benefit Reform: A Case Study in Tax-Transfer Integration." Canadian Tax Journal 47(5):1219-1257.

Battle, Ken, and Sherri Torjman. 1993. The Welfare Wall: Reforming the Welfare and Tax Systems. Ottawa: Caledon Institute of Social Policy.

Bennet, James. 1997. "Gore and Gephardt, Potential Rivals in 2000, Join in Criticizing of G.O.P. on Taxes," New York Times. 11 July: A16.

Bertram, Eva C. 2007. "The Institutional Origins of 'Workfarist' Social Policy." Studies in American Political Development 21(2): 203-229. http://dx.doi.org/10.1017/ s0898588x07000181

Best, Rachel K. 2012. "Disease Politics and Medical Research Funding : Three Ways Advocacy Shapes Policy." American Sociological Review 77(5):780-803. http://dx.doi .org/10 . $1177 / 0003122412458509$

Beveridge, William H. 1943. "Social Security: Some Trans-Atlantic Comparisons." Journal of the Royal Statistical Society 106(4):305-332. http://dx. doi .org/10.2307/2980480

Blair, Tony. 1999. "Beveridge Revisited: A Welfare State for the 21st Century," Pp. 7-18 in Ending Child Poverty, edited by Robert Walker. Bristol: The Policy Press.

Blake, Raymond B. 2009. From Rights to Needs: A History of Family Allowances in Canada, 1929-92. Vancouver: UBC Press.

Block, Fred. 2009. "Read Their Lips: Taxation and the Right-Wing Agenda." Pp. 68-85 in The New Fiscal Sociology: Taxation in Comparative and Historical Perspective, edited by Isaac W. Martin, Ajay K. Mehrotra, Monica Prasad. Cambridge: Cambridge University Press. http://dx.doi.org/10.1017/CB09780511627071.005

Brown, Hana E. 2013. "Race, Legality, and the Social Policy Consequences of AntiImmigration Mobilization." American Sociological Review 78(2):290-314. http://dx . doi.org/10.1177/0003122413476712

Brownlee, W. Elliot, and C. Eugene Steuerle 2004. "Taxation" Pp. 155-181 in The Reagan Presidency: Pragmatic Conservatism and Its Legacies, edited by W. Elliot Brownlee and Hugh David Graham. Lawrence: University Press of Kansas.

Burns, Eveline M. 1943. "The Beveridge Report." American Economic Review 33(3): 512-533. 
Canada. Department of Finance. 1978. Report on the Integration of Social Security Program Payments into the Income Tax System. Ottawa: Queen's Printer.

Canada. Department of Finance. 1984. A New Direction for Canada: An Agenda for Economic Renewal. Ottawa: Queen's Printer.

Canada. Department of National Health and Welfare. 1992. The Child Benefit: A White Paper on Canada's New Integrated Child Tax Benefit. Ottawa: Queen's Printer.

Canada. House of Commons. 1991. Canada's Children: Investing in our Future. Ottawa: Queen's Printer.

Canada. House of Commons. 1992. Minutes of Proceedings and Evidence of the Legislative Committee on Bill C-80. Ottawa: Queen's Printer.

Canada, Senate. 1991. Child Poverty: Toward a Better Future. Ottawa: Queen's Printer.

Carluccio, Teresa. 1993. Tax Expenditures for Social Policy: A Study of the Federal Child Tax Benefit System. ML Thesis, University of Toronto.

Cassidy, Harry M. 1943. "Review of Report on Social Security for Canada." American Economic Review 33(3):709-712.

Clinton Digital Library, Box 2, Folder 18. Domestic Policy Council and Elena Kagan, "Budget Materials [3]," 1997. Accessed July 12, 2013. http://clinton.presidentiallibraries.us/items/show/25797.

Clymer, Adam. 1992. "Senate Democrats' Tax Proposal is Less Generous Than House Bill." New York Times. 29 February: A1.

CQ Weekly. 1995. "PRESIDENTIAL VETO MESSAGE: Profound Differences' Cited In Veto of Budget Plan." CQ Weekly. 9 December: 3762-3763.

Cullen, Michael. 2004. Budget Speech 2004. Wellington: The Treasury.

Eidlin, Barry. 2015. "Class vs. Special Interest: Labor, Power, and Politics in the United States and Canada in the Twentieth Century." Politics and Society 43(2): 181-211. http: //dx.doi.org/10.1177/0032329215571280

Emigh, Rebecca J. 1997. "The Power of Negative Thinking: The Use of Negative Case Methodology in the Development of Sociological Theory." Theory and Society 26(5): 649-684. http://dx.doi.org/10.1023/A:1006896217647

Evans, Rowland and Robert Novak. 1993. "Reviving the Family Feud." Washington Post. 19 March: A31.

Ferrarini, Tommy, Kenneth Nelson, and Helena Höög. 2012. "The Fiscalization of Child Benefits in OECD Countries." Gini Discussion Paper 49.

Garfinkel, Irwin, Lee Rainwater, and Timothy Smeeding. 2010. Wealth and Welfare States: Is America a Laggard or Leader?. Oxford: Oxford University Press.

George, Alexander L., and Andrew Bennett. 2005. Case Studies and Theory Development in the Social Sciences. Cambridge: The MIT Press.

Gitterman, Daniel P. 2010. Boosting Paychecks: The Politics of Supporting America's Working Poor. Washington DC: Brookings Institution Press.

Guest, Dennis. 1999. The Emergence of Social Security in Canada. Vancouver: UBC Press.

Guetzkow, Joshua. 2010. "Beyond Deservingness: Congressional Discourse on Poverty, 1964-1996." The Annals of the American Academy of Political and Social Science 629: 173-197. http://dx.doi.org/10.1177/0002716209357404

Hacker, Jacob S. 2002. The Divided Welfare State: The Battle over Public and Private Social Benefits in the United States. Cambridge: Harvard University Press. http://dx.doi. org/10.1017/CB09780511817298 
Haddow, Rodney S. 1993. Poverty Reform in Canada 1958-1978: State and Class Influence on Policymaking. Montreal: McGill-Queen's University Press.

Hale, Geoffrey E. 2002. The Politics of Taxation in Canada. Peterborough: Broadview Press.

Herbert, Bob. 1997. "Topsy-Turvy Tax-Cut." New York Times. 30 June: A11.

HM Treasury. 1999. Supporting Children Through the Tax and Benefit System. The Modernization of Britain's Tax and Benefit System 5. London: HM Treasury.

Hodgson, Helen. 2005. "An Historical Analysis of Family Payments in Australia: Are They Fair or Simple?" Journal of the Australasian Tax Teachers Association 1(2):318-341.

Hodgson, Helen, and Rebecca Boden. 2008. "Not-so-distant Cousins: Family Benefits in the United Kingdom and Australia," International Social Security Review 61(3):29-46. http://dx.doi.org/10.1111/j.1468-246X.2008.00315.x

Howard, Christopher. 1997. The Hidden Welfare State: Tax Expenditures and Social Policy in the United States. Princeton: Princeton University Press.

Hunt, Albert. 1997. "This Republican Tax-Cut Dog Won't Hunt." Wall Street Journal. 26 June.

Katz, Michael. 1996. In the Shadow of the Poorhouse: A Social History Of Welfare In America, Tenth Anniversary Edition. New York: Basic Books.

Kitchen, Brigitte. 1979. "A Canadian Compromise: The Refundable Child Tax Credit." Canadian Taxation 1(3):44-51.

Klassen, Richard T. and Dan Buchanan. 2006. "Ideology, Policy, and Economy: Liberal, New Democratic and Conservative Reforms of Ontario's Welfare Program." Journal of Canadian Studies 40(3):186-209.

Korpi, Walter, and Joakim Palme. 1998. "The Paradox of Redistribution and Strategies of Equality: Welfare State Institutions, Inequality, and Poverty in Western Countries." American Sociological Review 63(5): 661-687. http: //dx. doi.org/10.2307/2657333

Leman, Christopher. 1980. The Collapse of Welfare Reform: Political Institutions, Policy, and the Poor in Canada and the United States. Cambridge: MIT Press.

Lieberson, Stanley. 1991. "Small N's and Big Conclusions: An Examination of the Reasoning in Comparative Studies Based on a Small Number of Cases." Social Forces 70(2): 307-320. http://dx.doi.org/10.1093/sf/70.2.307

Lipset, Seymour M. 1990. Continental Divide: The Values and Institutions of the United States and Canada. New York: Routledge.

Little, Margaret J.H. 1998. No Car, No Radio, No Liquor Permit: The Moral Regulation of Single Mothers in Ontario, 1920-1997. Toronto: Oxford University Press.

Lockhard, Charles. (2012). The Roots of American Exceptionalism. New York: Palgrave Macmillan Press. http://dx.doi.org/10.1057/9781137016409

Macnicol, John. 1980. The Movement for Family Allowances 1918-1945. London: Heinemann.

Maioni, Antonia. 1998. Parting at the Crossroads: The Emergence of Health Insurance and the United States and Canada. Princeton: Princeton University Press.

March, James, and Johan Olsen. 2008. "The Logic of Appropriateness." Pp. 689-708 in The Oxford Handbook of Public Policy, edited by Moran, Michael, Martin Rein, and Robert E. Goodin. Oxford: Oxford University Press. http://dx.doi.org/10.1093/oxfordhb/ 9780199548453.003 .0034

Marsh, Leonard C. (1943). Report on Social Security for Canada. Ottawa: King's Printer.

McCabe, Joshua, and Aaron Major. 2014. "The Adversarial Politics of Fiscal Federalism: Tax Policy and the Conservative Ascendancy in Canada, 1988-2008." Social Science History 38(3-4):333-358. http://dx.doi.org/10.1017/ssh.2015.28 
Meanwell, Emily, and Julie Swando. 2013. "Who Deserves Good Schools? Cultural Categories of Worth and School Finance Reform." Sociological Perspectives 56(4):495-522. http: //dx.doi.org/10.1525/sop.2013.56.4.495

Mettler, Suzanne. 2011. The Submerged State: How Invisible Government Policies Undermine American Democracy. Chicago: University of Chicago Press. http://dx.doi .org/ $10.7208 /$ chicago/9780226521664.001.0001

Mill, John Stuart. 1843. A System of Logic, Ratiocinative and Inductive. New York: Harper and Brothers.

Myles, John, and Paul Pierson. 1997. "Friedman's Revenge: The Reform of 'Liberal' Welfare States in Canada and the United States." Politics and Society 25(4): 443-472. http: //dx.doi.org/10.1177/0032329297025004004

National Commission on Children. 1990. Opening Doors for America's Children: Interim Report. Washington DC: The Commission.

National Commission on Children. 1991. Beyond Rhetoric: A New American Agenda for Children and Families. Washington DC: Government Printing Office.

National Council of Welfare. 1987. Welfare in Canada: The Tangled Safety Net. Ottawa: National Council of Welfare.

National Resources Planning Board. 1941. Security, Work, and Relief Policies. Washington DC: Government Printing Office.

Nolan, Patrick. 2002. New Zealand's Family Assistance Tax Credits: Evolution and Operation. New Zealand Treasury Working Paper 02/16. Wellington: New Zealand Treasury.

Ontario Social Assistance Review Committee. 1988. Transitions: Report of the Social Assistance Review Committee. Ottawa: Queen's Printer.

Patterson, James T. 1994. America's Struggle Against Poverty, 1990-1994. Cambridge: Harvard University Press. http://dx.doi.org/10.4159/harvard.9780674423718

Pedriana, Nicholas, and Robin Stryker. 1997. "Political Culture Wars 1960s Style: Equal Opportunity Employment-Affirmative Action and the Philadelphia Plan." American Journal of Sociology 103(3): 633-691. http://dx.doi.org/10.1086/231252

Pierson, Paul. 1994. Dismantling the Welfare State? Reagan, Thatcher, and the Politics of Retrenchment. Cambridge: Cambridge University Press. http://dx.doi .org/10.1017/ CB09780511805288

Pierson, Paul. 2001. The New Politics of the Welfare State. Oxford: Oxford University Press. http://dx.doi.org/10.1093/0198297564.001.0001

Prasad, Monica. 2006. The Politics of Free Markets: The Rise of Neoliberal Economic Policies in Britain, France, Germany, and the United States. Chicago: University of Chicago Press.

Primus, Wendell E. 1989. "Children in Poverty: A Committee Prepares for an Informed Debate," Journal of Policy Analysis and Management 8(1):23-34. http://dx.doi .org/ $10.2307 / 3324421$

Quadagno, Jill. 1994. The Color of Welfare: How Racism Undermined the War on Poverty. New York: Oxford University Press.

Rector, Robert, and Stuart Butler. 1991. Reducing the Tax Burden on the Embattled American Family. Washington DC: Heritage Foundation.

Rubin, Alissa J. 1996. "Tax Cut Free-for-All." CQ Weekly. 8 March: 580.

Rubin, Alissa J., and David Hosansky. 1997. "TAXES: Democrats Steamrolled in House But Find Senate GOP Obliging." CQ Weekly. 28 June: 1495-1497. 
Schäfer, Armin, and Wolfgang Streeck. 2013. Politics in the Age of Austerity. Cambridge: Polity Press.

Schneider, Anne L., and Helen M. Ingram. 2005. Deserving and Entitled: Social Constructions and Public Policy. Albany: SUNY Press.

Seltzer, Lawrence. 1968. The Personal Exemptions in the Income Tax. New York: National Bureau of Economy Research.

Sewell, William H. 1992. "A Theory of Structure: Duality, Agency, and Transformation." American Journal of Sociology 98(1): 1-29. http://dx . doi .org/10.1086/229967

Shapiro, Isaac, and Robert Greenstein. 1997. House Ways and Means Child Tax Credit Proposal. Washington DC: Center for Budget and Policy Priorities.

Skocpol, Theda. 1992. Protecting Soldiers and Mothers: The Political Origins of Social Policy in the United States. Cambridge: Harvard University Press.

Skrentny, John D. 2006. "Policy-Elite Perceptions and Social Movement Success: Understanding Variations in Group Inclusion in Affirmative Action." American Journal of Sociology 111(6): 1762-1815. http://dx.doi.org/10.1086/499910

Somers, Margaret R., and Fred Block. 2005. "From Poverty to Perversity: Ideas, Markets, and Institutions over 200 Years of Welfare Debate." American Sociological Review 70(2): 260-287. http://dx.doi.org/10.1177/000312240507000204

Stanton, David, and Michael Fuery. 1995. "Developments in Family Payments, 1983-96." Social Security Journal 4(2):120-156.

Steensland, Brian. 2008. The Failed Welfare Revolution: America's Struggle over Guaranteed Income Policy. Princeton: Princeton University Press.

Steuerle, Eugene C. 1983. "The Tax Treatment of Households of Different Size" Pp. 73-97 in Taxing the Family, edited by Rudolph G. Penner. Washington D.C.: American Enterprise Institute.

Steuerle, Eugene C., and Jason Juffras. 1991. "A \$1000 Tax Credit for Every Child: A Base of Reform for the Nation's Tax, Welfare and Health Systems," Policy Paper. Washington, DC: Urban Institute.

Streeck, Wolfgang, and Kathleen Thelen. 2005. Beyond Continuity: Institutional Change in Advanced Political Economies. Cambridge: Cambridge University Press.

U.S. House. 1985a. Hearing before the Select Committee on Children Youth and Families. Tax Policy: What Do Families Need?. Washington DC: Government Printing Office.

U.S. House. 1985b. Hearing before the Committee on Ways and Means. Tax Burdens of Low-Income Wage Earners. Washington DC: Government Printing Office.

U.S. House. 1991a. Hearing before the Select Committee on Children, Youth, and Families. Reclaiming the Tax Code for American Families. Washington DC: Government Printing Office.

U.S. House. 1991b. Hearing before the Committee on the Budget. Challenging Distribution of Taxes and Income of Working People. Washington DC: Government Printing Office.

U.S. House. 1991c. Hearing before the Committee on Ways and Means. U.S. Economy, and Proposals To Provide Middle-Income Tax Relief, Tax Equity and Fairness, Economic Stimulus and Growth. Washington DC: Government Printing Office.

U.S. Senate. 1991a. Hearing before the Committee on Labor and Human Resources. Caught in the Squeeze: Economic Pressures on Working Families. Washington DC: Government Printing Office.

U.S. Senate. 1991b. Hearing before the Committee on Finance. Middle-Income Tax Cuts. Washington DC: Government Printing Office. 
Waldfogel, Jane. 2010. Britain's War on Poverty. New York: Russell Sage Foundation.

Washington Post. 1997. "Editorial." Washington Post. 29 June: C6.

Weaver, R. Kent. 2000. Ending Welfare as We Know It. Washington DC: Brookings Institution Press.

Wednesday Group. 1991. Moving Ahead: Initiatives for Expanding Opportunity in America. Washington, DC: The House Wednesday Group.

White House Working Group on the Family. 1986. The Family: Preserving America's Future. Washington DC: Domestic Policy Council.

Wiegers, Wanda. 2002. The Framing of Poverty as "Child Poverty" and Its Implications for Women. Ottawa: Status of Women Canada.

Witte, Edwin E. 1945. "1944-1945 Programs for Postwar Social Security and Medical Care." Review of Economics and Statistics 27(4):171-188. http://dx. doi .org/10.2307/1927902

York, Geoffrey. 1991. "New Deal for Low-Income Families Expected Next Week." Globe and Mail. 7 May.

York, Geoffrey. 1992. "Tory Politicians Form Family Compact." Globe and Mail. 3 June: A1.

Acknowledgements: We would like to thank Nadya Hajj, Sarah Quinn, and audiences at the University of Toronto and Social Science History Association for comments on various versions of this article.

Joshua T. McCabe: The Freedom Project, Wellesley College. E-mail: jmccabe@wellesley.edu.

Elizabeth Popp Berman: Department of Sociology, University at Albany, SUNY.

E-mail: epberman@albany.edu. 